\title{
Callus and shoot induction of leaf culture Lilium longiflorum with NAA and BAP
}

\author{
NI KADEK DWIPAYANI LESTARI ${ }^{1, \bullet}$, NI WAYAN DESWINIYANTI ${ }^{1}$, IDA AYU ASTARINI ${ }^{2}$, \\ NI LUH MADE ARPIWI ${ }^{2}$ \\ ${ }^{1}$ Department Program of Biology, Faculty of Health, Science and Technology, Universita Dhyana Pura. Jl. Raya Padang Luwih, Tegaljaya, Dalung, \\ Badung 80361, Bali, Indonesia. Tel.: +62-361-426450, Fax.: +62-361-426452, `email: dwipayanilestari@undhirabali.ac.id \\ ${ }^{2}$ Department of Biology, Faculty of Mathematics and Natural Sciences, Universita Udayana. Jl. Raya Kampus Unud No. 9, Bukit Jimbaran, Badung, Bali \\ 80361, Bali, Indonesia
}

Manuscript received: 21 May 2019. Revision accepted: 12 September 2019.

\begin{abstract}
Lestari NKD, Deswiniyanti NW, Astarini IA, Arpiwi NLM. 2019. Callus and shoot induction of leaf culture Lilium longiflorum with NAA and BAP. Nusantara Bioscience 11: 162-165. Lilium longiflorum Thunb., an Easter lily, is a common ornamental plant used as potted plant, cut flower, cosmetic and medicine. The research on tissue culture technique to induce shoots and callus is expected to increase the yield of lilies quickly and efficiently. This study aims to determine the effect of plant growth regulator combination of Naphthalene Acetic Acid (NAA) and Benzyl Amino Purine (BAP) on the development of leaf culture and the best concentration for callus induction and shoots of lily plants. This study was conducted in a completely randomized design using leaf explants in Vacin and Went medium, with combination of NAA and BAP $\left(0 ; 0.5 ; 1 \mathrm{mg} . . \mathrm{L}^{-1}\right)$ as the treatments. The result of the eight-week observations shows that the plant growth regulators significantly affected either in days initiation callus, days initiation of shoot, percentage of callus, percentage of shoot, diameter of callus, no of shoot and length of shoot. The combination of $1 \mathrm{mg} . \mathrm{L}^{-1} \mathrm{NAA}$ and BAP had the best effect in the percentage of explants forming shoots (100\%), means number of shoots (5.8), and means length of shoot $(11.6 \mathrm{~cm})$.
\end{abstract}

Keywords: BAP, callus, leaf culture, Lilium, NAA

\section{INTRODUCTION}

Easter lily or Lilium longiflorum Thunb. is a high value and a popular horticulture ornamental plants and ranks fourteen in the international flower trade because of beautiful, fascinating form of flowers and long vase life (Ranjana et al. 2008; Pandey et al. 2009; Sajid et al. 2009). Lily is one of common ornamental plants which is useful as potted plants, garden plant, cut flowers, cosmetics, and medicine. It has very low propagation rate from bulb scales and produces only 1-2 bulblets in one year which is not sufficient for large scale cultivation of this plant (Kumar et al. 2006).

For propagation material in Indonesia, lily seeds are currently imported. Data from the Directorate General of Horticulture in 2014 showed that the volume of lily seeds imported into Indonesia reached 2,252,176, while the outgoing seeds reached 12,960,240 pieces which were produced by PT. Tamara Stekindo in Sumatra. The imported seeds are ready flowering tubers, while the exported ones are in micro bulbs. The data show that necessary for lily seeds is very high and cannot be fulfilled by domestic production. Therefore, mass propagation method properly for lilies is needed. One of the best and most prolific vegetative propagation methods for lilies is using in vitro culture (Bahr and Compton 2004).

The combination of plant growth regulators added to the medium becomes the main factor determining the success of in vitro culture. The plant growth regulator (PGR) which is often used to induce the formation of callus is auxin. Among the auxin groups, 2,4Dichlorophenoxyacetic acid and Naphthalene Acetic Acid (NAA) are commonly used in tissue culture media. Auxin (2,4 D and NAA) is usually used to induce callus formation (Suryowinata 1996). On the other hand, cytokines treatment in callus culture plays an important role in triggering cell division and elongation so that it can accelerate the development and growth of callus. One group of cytokines that is often used in tissue culture method is Benzyl Amino Purine (BAP); since the BAP is stable, it is easy to obtain and more effective than kinetin (Gunawan 1992).

Different sources of explants from lilies, including bulb scales (Han et al. 2004; Kumar et al. 2007; Min-Ji et al. 2012), leaves (Kim et al. 2005; Ling-Fei et al. 2009), receptacle (Doung 2003) and callus have a potential for micropropagation, rapid multiplication, and commercialization. Leaf explant has a weaker regeneration capacity than other explants (Niimi 1995). Therefore, it needs the right method and combination of growth regulators to multiply plants from leaf explant Lilium. This study describes a method and the results of regeneration of shoot and callus growth from leaf explants Lilium longiflorum with combination of growth regulators of NAA and BAP. 


\section{MATERIALS AND METHODS}

\section{Plant material and pre-culture treatment}

Young leaves on the terminal part of the Lily (Lilium longiflorum) plant in mature age (1 year) were used as explant in this study. The leaves were surface-sterilized in running tap water for 10 minutes. Leaf explants often experience browning during culture; thus, pre-culture treatment is carried out to minimize browning in explants by soaking it into the antioxidant solution, dipped and shaken in $150 \mathrm{mg} . \mathrm{L}^{-1}$ citric acid and $100 \mathrm{mg} . \mathrm{L}^{-1}$ ascorbic acid for $30 \mathrm{~min}$ (Gulzar et al. 2016).

\section{Explant sterilization}

After explant was dipped in liquid detergent for $10 \mathrm{~min}$ and rinsed with sterile water, explant was dipped in $5 \%$ and $10 \%$ sodium hypochlorite with 3 drops tween-20 for 10 min. The sterilization process was continued in a laminar airflow cabinet by dipping the explants in $70 \%$ ethanol for $5 \mathrm{~min}$ and rinsed with sterile water. After surface sterilization, the explants were inoculated in culture media. Leaf explants were put into laminar airflow and the UV light was turned on for 10 minutes. Leaf explants were cut $\pm 3 \mathrm{~cm}$ above the petri dish with a scalpel and planted on the media in a vertical position.

\section{Media and culture condition}

The in vitro culture media used in this experiment is Vacin and Went media supplemented with 20 g. $\mathrm{L}^{-1}$ sucrose and $8 \mathrm{~g} / \mathrm{l}$ agarose. Various combinations of NAA and BAP were used as treatments, consisting of $0 \mathrm{mg} . \mathrm{L}^{-1} \mathrm{NAA}$ and BAP, $0.5 \mathrm{mg} . \mathrm{L}^{-1} \mathrm{NAA}$ and BAP and $1 \mathrm{mg} . \mathrm{L}^{-1} \mathrm{NAA}$ and BAP. The $\mathrm{pH}$ of the media was adjusted at 5.6-5.8 before autoclaving at $121^{\circ} \mathrm{C}$ and 15 psi for 15 minutes. Inoculated explants were incubated in the culture room at $25^{\circ} \mathrm{C}$ and cool-white fluorescent lamps with $16 \mathrm{~h}$ photoperiod under.

\section{Observation of variables}

After eight weeks of observation of growing time, the number of callus and shoot growth and callus color, explant

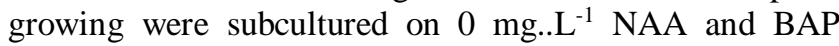
media, $0.5 \mathrm{mg} . \mathrm{L}^{-1} \mathrm{NAA}$ and BAP, $1 \mathrm{mg} . \mathrm{L}^{-1} \mathrm{NAA}$ and BAP according to the media treatment used. In the subculture process, the length of the shoots that grows and the diameter of the callus are measured

\section{Data analysis}

All treatments were repeated five times performed by completely randomized design. Data were analyzed using analysis of variance and continued with Duncan's Multiple Range Test (DMRT) at $\alpha=0.05$ to identify the differences between treatments (Gomez and Gomez 1984).

\section{RESULTS AND DISCUSSION}

The analysis results show that it was not significantly different in variable days initiation, percentage of callus and diameter of callus, while it was significantly different in the variable percentage (\%) of shoot, number of shoot and length of shoot. In this study, the fastest days initiation for callus was mean 4.8 days on modification medium 1 mg. $\mathrm{L}^{-1} \mathrm{NAA}$ and BAP and followed by medium $0.5 \mathrm{mg} . \mathrm{L}^{-1}$ NAA and BAP mean 5.0 days. Percentage, diameter, morphology, and color of callus are same between medium $0.5 \mathrm{mg} . \mathrm{L}^{-1} \mathrm{NAA}$ and BAP and $1 \mathrm{mg} . \mathrm{L}^{-1} \mathrm{NAA}$ and BAP (Table 1).

Initiation shoot was mean 24 days on medium $0 \mathrm{mg} . \mathrm{L}^{-1}$ NAA and BAP and mean 19,4 days on medium $1 \mathrm{mg} . \mathrm{L}^{-1}$ NAA and BAP. Percentage, number, and length of shoot showed the highest result in medium $1 \mathrm{mg} . \mathrm{L}^{-1} \mathrm{NAA}$ and BAP (Table 2).

Table 1. Callus induction of leaf culture of Lilium longiflorum

\begin{tabular}{|c|c|c|c|c|c|}
\hline \multicolumn{2}{|c|}{ PGR (mg.L $\left.{ }^{-1}\right)$} & \multirow{2}{*}{$\begin{array}{l}\text { Days for initiation } \\
\text { Callus }\end{array}$} & \multirow{2}{*}{$\%$ Callus } & \multirow{2}{*}{$\begin{array}{l}\text { Diameter } \\
\text { (cm) }\end{array}$} & \multirow[t]{2}{*}{ Color } \\
\hline NAA & BAP & & & & \\
\hline 0 & 0 & $0.0 \pm 0.0^{\mathrm{a}}$ & $0.0 \pm 0.0^{\mathrm{a}}$ & $0.0 \pm 0.0^{\mathrm{a}}$ & - \\
\hline 0.5 & 0.5 & $11.0 \pm 2.7^{\mathrm{b}}$ & $80.0 \pm 4.8^{b}$ & $0.16 \pm 0.04^{b}$ & yellowish-white \\
\hline 1 & 1 & $11.6 \pm 0.4^{\mathrm{b}}$ & $80.0 \pm 4.8^{\mathrm{b}}$ & $0.20 \pm 0.00^{\mathrm{b}}$ & yellowish-white \\
\hline
\end{tabular}

Note: Values represent the mean + S.E. means followed by different letters are significantly different at $\mathrm{P}=0.05$ according to the least significant test.

Table 2. Shoot induction of leaf culture of Lilium longiflorum

\begin{tabular}{|c|c|c|c|c|c|}
\hline \multicolumn{2}{|c|}{ PGR (mg.L L $\left.^{-1}\right)$} & \multirow{2}{*}{$\begin{array}{c}\begin{array}{c}\text { Days for initiation } \\
\text { shoot }\end{array} \\
\end{array}$} & \multirow[t]{2}{*}{$\%$ shoot } & \multirow[t]{2}{*}{ No of shoot } & \multirow{2}{*}{$\begin{array}{c}\text { Length } \\
\text { (cm) }\end{array}$} \\
\hline NAA & BAP & & & & \\
\hline 0 & 0 & $24.0 \pm 0.5^{b}$ & $80.0 \pm 20.0^{\mathrm{b}}$ & $1.8 \pm 0.4^{\mathrm{b}}$ & $8.0 \pm 2.0^{\mathrm{b}}$ \\
\hline 0.5 & 0.5 & $0.0 \pm 0.0^{\mathrm{a}}$ & $0.0 \pm 0.0^{\mathrm{a}}$ & $0.0 \pm 0.0^{\mathrm{a}}$ & $0.0 \pm 0.0^{\mathrm{a}}$ \\
\hline 1 & 1 & $19.4 \pm 0.4^{b}$ & $100.0 \pm 0.0^{\mathrm{b}}$ & $5.8 \pm 0.5^{\mathrm{c}}$ & $11.6 \pm 0.2^{b}$ \\
\hline
\end{tabular}

Note: Values represent the mean + S.E. means followed by different letters are significantly different at $\mathrm{P}=0.05$ according to the least significant test 


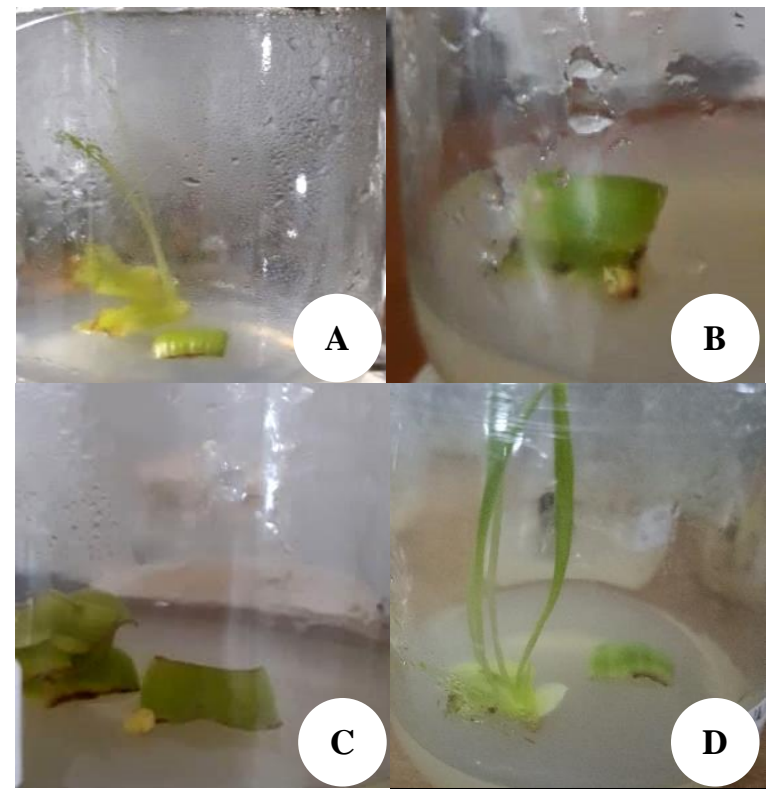

Figure 1. (a) shoot on $0 \mathrm{mg} . \mathrm{L}^{-1} \mathrm{NAA}$ and $\mathrm{BAP}$, (b) callus on 0.5 mg NAA and BAP, (c) callus on 1 mg. $\mathrm{L}^{-1} \mathrm{NAA}$ and BAP, (d) Callus and shoot on $1 \mathrm{mg} . \mathrm{L}^{-1} \mathrm{NAA}$ and BAP

\section{Discussion}

\section{Initiation callus}

The results were significantly different in the variable days for initiation callus from VW media without plant growth regulator without callus growth. The fastest day for initiation callus was found in modification VW medium with $0.5 \mathrm{mg} . \mathrm{L}^{-1} \mathrm{NAA}$ and $0.5 \mathrm{mg} . \mathrm{L}^{-1} \mathrm{BAP}$ (11 days) and followed by medium with $1 \mathrm{mg} . \mathrm{L}^{-1} \mathrm{NAA}$ and BAP (11.6 days). The fastest initiation days for initiation callus and shoot in this study were found in the modification on medium with addition of plant growth regulator. Addition of plant growth regulator on medium tissue culture played an important role in triggering cell division and elongation so that it was able to accelerate the development and growth (Gunawan et al. 1992). This is in line with the study by Naing et al (2014) reporting that culture leaf explants $L$. longiflorum Thunb. after 15 days of culture showed elongation and enlargement.

Variable of percentage number of callus showed significantly different results. The concentration of 0.5 mg.L ${ }^{-1}$ NAA and 0.5 mg. $L^{-1}$ BAP produced callus, while the concentration of $1 \mathrm{mg} . \mathrm{L}^{-1} \mathrm{NAA}$ and $1 \mathrm{mg} . \mathrm{L}^{-1}$ BAP produced callus organogenesis to shoot. Research by Prihantini et al. (2018) shows similar results in which the callus were developed from tissue culture of Artemisia annua on MS medium with combination of plant growth regulators: NAA $0.5 \mathrm{mg} . \mathrm{L}^{-1}+$ BA $0.5 \mathrm{mg} . \mathrm{L}^{-1}$; NAA $0.5 \mathrm{mg} . \mathrm{L}^{-1}+$ kinetin 0.5 mg.L ${ }^{-1}$; 2,4-D $0.5 \mathrm{mg} . \mathrm{L}^{-1}+$ BA $0.5 \mathrm{mg} . \mathrm{L}^{-1}$; and 2,4-D 0.5 $\mathrm{mg} \cdot \mathrm{L}^{-1}+$ kinetin $0.5 \mathrm{mg} \cdot \mathrm{L}^{-1}$. To get callus, it requires a combination of the type of media and properly treatment. Satiew and Umamanit (2015) report that callus formation was obtained from the leaf explants cultured on the medium supplemented with plant growth regulator after culturing under dark condition for four weeks. The callus was regenerated to form shoots during incubation in light. In vitro lily propagation is influenced by several factors including type of media, photoperiod, growth-regulating agent, type of sugar and type of explants (Chang et al. 2000; Tan Nhut et al. 2001). Santoso and Fatimah (2004) make a significant callus inducing of certain plant parts, which are hormonally stimulated. The suitability and accuracy of the type selection and the balance of the concentration of growth-regulating substances used will affect the success of callus formation on the explants used.

Diameter and color of callus have the same results on both media with the addition of NAA and BAP. After callus is grown, callus does not divide and grow but organogenesis occurs into shoots on medium $1 \mathrm{mg} . \mathrm{L}^{-1}$ NAA and BAP. Induction callus and regeneration to shoots and leaf cannot be found in medium $1 \mathrm{mg} . \mathrm{L}^{-1} \mathrm{NAA}$ and BAP, but in medium $0.5 \mathrm{mg} . \mathrm{L}^{-1} \mathrm{NAA}$ and $\mathrm{BAP}$ of induction callus without organogenesis being a shoot. Yusnita et al. (2011) state that this is referred to as indirect organogenesis, explants that show organogenesis response does not directly form yellowish-white callus, especially before formation of adventitious shoot. Hicks (1994) put forward the same thing, namely, there are two different patterns of development in organogenesis, namely organogenesis directly, where organs are formed from explant cells without through indirect callus and organogenesis formation, which through formation callus first before becoming shoot.

\section{Initiation shoot}

The variable day for initiation of shoot result is significantly different from the fastest days initiation shoot in combination of $1 \mathrm{mg} . \mathrm{L}^{-1} \mathrm{NAA}$ and $1 \mathrm{mg} . \mathrm{L}^{-1}$ BAP following $0 \mathrm{mg} . \mathrm{L}^{-1} \mathrm{NAA}$ and $0 \mathrm{mg} . \mathrm{L}^{-1}$ BAP giving BAP combined with NAA, it turns to outproduce shoots that are faster extension, but concentration combinations have a profound effect. In this study, medium $0.5 \mathrm{mg} . \mathrm{L}^{-1} \mathrm{NAA}$ and $0.5 \mathrm{mg} . \mathrm{L}^{-1}$ BAP cannot grow shoots but can grow callus, but the control medium can grow shoots. The control medium can grow shoots due to the presence of endogenous auxin in the explant itself which can help shoot growth. Reinhardt et al. (2000) state that endogenous auxin in plants has important role in the growth of explant organogenesis. In addition, explant source pieces also play an important role in the formation of organogenesis, in which the base, middle and tips of leaf will give different speed and growth results (Magendans 1988).

The combination of medium $1 \mathrm{mg} . \mathrm{L}^{-1} \mathrm{NAA}$ and 1 mg. $\mathrm{L}^{-1}$ BAP in this study can be said as a good combination to grow shoot from leaf explants of Lilium longiflorum plants compared to other media. In the variable percentage, number and length of shoots were significantly different from the highest percentage, number and length of shoots in $1 \mathrm{mg} . \mathrm{L}^{-1} \mathrm{NAA}$ and $1 \mathrm{mg} . \mathrm{L}^{-1}$ BAP (Table 2). The percentage and number of shoots become the most important factors in propagation in vitro culture. The more shoots that are formed, the more opportunities obtained by prospective plants (Sari et al. 2015). Naing et al. (2013) report their study on middle part of leaf explants Lilium longiflorum hybrid Bright tower showing that the best combination medium was $1.5 \mathrm{mg} . \mathrm{L}^{-1} \mathrm{NAA}$ and $1 \mathrm{mg} . \mathrm{L}^{-1}$ $\mathrm{BA}$, the result of $96.5 \%$ shoot induction with 5.6 number of 
shoots. In addition, the balanced growth regulators are used for shoot induction, while the use of an explant source also affects the success of shoot induction (Shofiyani and Hajoeningtijas 2010). Similar result from Yashinta and Menwangi (2019) shows greater increase in shoot growth

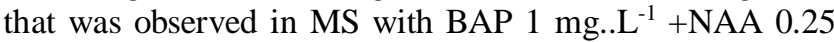
mg... $\mathrm{L}^{-1}$ +TDZ $0.5 \mathrm{mg} . \mathrm{L}^{-1}$ media to micropropagation Morus canaya.

The highest shoot height was $12 \mathrm{~cm}$ with an average of $11.6 \mathrm{~cm}$ in the treatment of $1 \mathrm{mg} . \mathrm{L}^{-1} \mathrm{NAA}$ and $1 \mathrm{mg} . \mathrm{L}^{-1}$ BAP (Table 2). Naphthaleneacetic Acid (NAA) is a functioning auxin hormone in inducing cell elongation and rooting initiation. Meanwhile, hormones 6-Benzylamino Purin (BAP) functions stimulated cell division in tissues explants and stimulates growth shoot (Wattimena 1991). Sari et al. (2015) state that the role of BAP in stimulating the growth of shoots was more effective, when the medium enough auxin culture was available. Kristina (2009) reports that if the addition of NAA hormone was higher than BAP, it would trigger root growth more than shoots. Research conducted by Mir et al. (2012) shows that micropropagation protocol in Lilium longiflorum with MS medium combination $2 \mathrm{mg} . \mathrm{L}^{-1} \mathrm{NAA}$ and $0 \mathrm{mg} . \mathrm{L}^{-1} \mathrm{BA}$ was the most effective thing for rooting and giving maximum rooting $(93 \%)$ and combination with BA $2.0 \mathrm{mg} . \mathrm{L}^{-1}+\mathrm{NAA}$ $0.5 \mathrm{mg} . \mathrm{L}^{-1}$ was most bulblet regeneration (94\%), and maximum shoot length $(12 \mathrm{~cm})$.

in conclusion, the VW media containing $1 \mathrm{mg} . \mathrm{L}^{-1} \mathrm{NAA}$ $+1 \mathrm{mg} . \mathrm{L}^{-1} \mathrm{BAP}$ is the best combination for in vitro culture of Lilium longiflorum Thunb. using leaf explant resulted in the highest percentage of explants forming shoots $(100 \%)$, number of shoots (5.8), shoot length (5.6) and means percentage of callus $(80 \%)$. On the other hand, the VW medium containing $0,5 \mathrm{mg} . \mathrm{L}^{-1} \mathrm{NAA}+0.5 \mathrm{mg} \cdot \mathrm{L}^{-1}$ BAP includes callus formation $(80 \%)$ without organogenesis.

\section{ACKNOWLEDGEMENTS}

The authors would like to thank The Ministry of Research, Technology \& Higher Education of Republic of Indonesia for providing financial support, contract No. 016/UNDHIRA-LP2M/PN/2018.

\section{REFERENCES}

Bahr LR, Compton ME. 2004. Competence for in vitro bulblet regeneration among eight Lilium genotypes. Hort Sci 39 (1): 127-129.

Chang C, Chen CT, Ching Tsai Y, Chang WC. 2000. A Tissue culture protocol for propagation of a rare plant Lilium speciosum Thunb.var. gloriosoides Baker. Bot Bull Acad Sin 41: 139-142.

Directorate General of Horticulture. 2014. Income and expenditure data horticultural crop seeds in 2014. The Directorate General of Horticulture, Jakarta. [Indonesian]

Doung TN. 2003. The control of in vitro direct main stem formation of Lilium longiflorum derived from receptacle culture and rapid propagation by using in vitro stem nodes. Plant Growth Regul 40: 179-184.

Gomez KA, Gomez AA. 1984. Statistical Procedures for Agricultural Research. John Wiley \& Sons, New York.

Gulzar A, Muhammad JJ, Yasar S, Ahsan A. 2016. Effect of antioxidants, amino acids and plant growth regulators on in vitro propagation of Rosa centifoli. Iran J Biotech 14 (1): 52-55.
Gunawan LW, Wattimena GA, Mattjik NA, Syamsudin E, Wieni NMA, Ernawati A. 1992. Bioteknologi Tanaman. IPB, Bogor. [Indonesian]

Han BH, Yu HJ, Yae BW, Peak KY. 2004. In vitro micropropagation of Lilium longiflorum 'Georgia' by shoot formation as influenced by addition of liquid medium. Sci Hort 103: 39-49

Hicks G. 1994. Shoot induction and organogenesis in vitro: a developmental perspective. In Vitro Cell Dev Biol-Plant 301: 10-15.

Kim MS, Jeon JH, Youm JW, Kim JH, Lee BC, Kang WJ, Kim HS, Joung H. 2005. Efficient plantlet regeneration via callus induction from leaf explants in Lilium oriental hybrid 'Casa Blanca'. J Plant Biotech 7: 129-134.

Kristina NN. 2009. Induction of Tabato barito (Ficus deltoidea Jack) shoots in vitro using Benzyl Adenine (BA) and Naphthalene Acetic Acid (NAA). Littri J Bogor Res Inst Med Aromat Plants 15 (1): 33 39.

Kumar S, Awasthi V, Kanwar JK. 2007. Influence of growth regulators and nitrogenous compounds on in vitro bulblet formation and growth in oriental lily. Hort Sci 34: 77-83.

Kumar S, Kanwar JK, Sharma DR. 2006. In vitro propagation of Lilium. Adv Hortic Sci 20 (2): 181-188.

Ling-Fei X, Feng Wang M, Dong L. 2009. Plant regeneration from in vitro cultured leaves of Lanzhou lily (Lilium davidii var. unicolor). Sci Hortic199: 458-461.

Magendans JFC. 1988. Morphogenesis of Primary Vascular Tissue and Regeneration. Agriculture University Wageningen Papers, The Netherlands.

Min-Ji K, Ramzan F, Yun-Jae, Yoon-Jung A, Yunim H, Chang-Kil K, Younis KA. 2017. Chromosomal analysis of Lilium longiflorum x Asiatic hybrids using GISH (genomic in situ hybridization). Hortic Environ Biotechnol 58 (6): 591-600.

Mir JI, Ahmed N, Itoo H, Sheikh MA, Rizwan R, Shabir H W. 2012. In vitro propagation of Lilium (Lilium longiflorum). Indian J Agric Sci 82 (5): 455-458.

Naing AN, Yuna H, Lucidosa J, Hwanga YJ, Kima KM, Ahnb BJ, Lima KB. 2014. Plant regeneration through various explants of Lilium longiflorum hybrid "Bright Tower" and determination of ploidy level of regenerated plants. Plant Biosyst 148 (2): 191-199.

Niimi Y . 1995. In vitro propagation and post-in-vitro establishment of bulblets of Lilium japonicum Thunb. Jpn Soc Hortic Sci 63: 843-52.

Pandey RK, Singh AK, Sharma M. 2009. In vitro propagation of Lilium. An Int J 1 (2): 26-28.

Prihantini AI, Sukito A, Tachibana S. 2018.Production of antioxidant compound from tissue culture of Artemisia annua. Nusantara Biosci 10: 251-255.

Ranjana K, Kumar S, Kanwar JK, Mahajan PK. 2008. In vitro bulblet productivity in different explants of hybrid lilies. J Fruit Ornam Plant Res 16: 345-352.

Reinhardt D, Mandel T, Kuhlemeier C, 2000. Auxin regulates the initiation and radial position of plant lateral organs. Plant Cell 12 (4): 507-518.

Sajid GM, Kaukab M, Ahmad Z. 2009. Foliar application of Plant Growth Regulators (PGR) and nutrients for improvement of lily flowers. Pak J Bot 41 (1): 233-237.

Santoso U, Fatimah N. 2004. Kultur Jaringan 2. UMM Press, Malang. [Indonesian]

Sari HS, Murni D, Iman B. 2015. Efek NAA dan BAP terhadap pembentukan tunas, daun, dan tinggi tunas stek mikro Nepenthes ampullaria Jack Biosfera 32 (3): 194-201. [Indonesian]

Satiew K, Umamanit T. 2015. Micropropagation of Lilium formolongo via leaf explants. Int J Agric Technol 11 (4): 855-862.

Shofiyani A, Hajoeningtijas. 2010 . Pengaruh sterilan dan waktu perendaman pada eksplan daun kencur ( Kaemferia galanga L) untuk meningkatkan keberhasilan kultur kalus. Agritech 12: 11-29. [Indonesian]

Suryowinata M. 1996. Pemuliaan Tanaman secara In vitro. Kanisius, Yogyakarta. [Indonesian]

Tan Nhut D, Van Le B, Tanaka M, Thanh Van KR. 2001. Shoot induction and plant regeneration from receptacle tissue of Lilium longiflorum. Sci Hortic 87: 131-138.

Wattimena GA. 1991. Zat Pengatur Tumbuh. IPB, Bogor. [Indonesian]

Yashinta REW, Menwangi NH. 2019. Micropropagation of Morus cathayana through in vitro culture from local Bogor, West Java, Indonesia. Nusantara Biosci 11 (1): 18-22.

Yusnita, Pungkastiani W, Hapsoro D. 2011. In vitro organogenesis of two Sansevieria cultivars on different concentrations of benzyladenine (BA). Agrivita 33 (2): 147-153. 
NUSANTARA BIOSCIENCE

Vol. 10, No. 1, pp. xxxx

February 2018
ISSN: 2087-3948

E-ISSN: 2087-3956 DOI: $10.13057 /$ nusbiosci/n1001xx 